\title{
Comparison of three anode channel configurations and their effects on DMFC performance
}

\author{
S.SH.Khoshmanesh ${ }^{1, *}$, S.Bordbar ${ }^{2}$ \\ ${ }^{1}$ Islamic Azad University, Khormoj branch, khormoj, Boushehr, Iran \\ ${ }^{2}$ Petroiran company, Tehran, Iran \\ * Corresponding author. Tel: +987726240716, Fax: +987726240286, E-mail: sharif.khoshmanesh@gmail.com
}

\begin{abstract}
Here the 3D two phase homogenous CFD modeling for the anode channel and 1D two phase mathematical modeling for the porous media were considered. The challenging issue is to define the interface boundary conditions such as gradient of $\mathrm{CO} 2$ and methanol mass fraction between the diffuser layer and the anode channel. To overcome this difficulty, CFD modeling in the anode channel and mathematical modeling in the porous media were coupled. This combination models gives an accurate model to evaluate the cell performance and also to predict accumulation of $\mathrm{CO} 2$ in the channel and its negative effects on the cell performance. Output results of the combination's model are in very good agreement with the experimental data. The distribution of $\mathrm{CO} 2$ in the anode channel shows that the accumulation of $\mathrm{CO} 2$ in the MSFF is less than SSFF and PFF configuration so the negative effect of $\mathrm{CO} 2$ decrease in the MSFF case relative to two other cases. Accumulation of $\mathrm{CO} 2$ is more in the channel rib relative to other places of channel. This is true for all three channel configurations.

The cell voltage-Current density graph shows that the MSFF performance is better than two other cases. Comparing MSFF configuration with the SSFF shows that the performance of MSFF is a little more than SSFF.
\end{abstract}

Keywords: Direct methanol fuel cell, Anode flow configurations, CFD modeling, Mathematical modeling

\section{Nomenclature}

$\mathrm{C}_{0} \quad$ Average concentration of methanol at the channel/ADL interface.................. molm $^{-3}$ $\mathrm{C}_{\mathrm{I}} \quad$ Concentration of methanol at the ADL/ACL interface......................... molm $^{-3}$ $\mathrm{C}_{\mathrm{II}} \quad$ Concentration of methanol at the ACL/membrane interface .................. molm $^{-3}$ C Molar Concentration ...............kmolm ${ }^{-3}$ D Diffusion coefficient ................ $\mathrm{m}^{2} \mathrm{~s}^{-1}$ X Mass fraction

F Faraday's constant, 96,487..... Cequiv

$I_{\text {Cell }} \quad$ Cell current density.....................Am ${ }^{-2}$

$I_{\text {Leak }} \quad$ Leakage current density ............ Am ${ }^{-2}$

$I_{o, r e f}^{\mathrm{MeOH}} \quad$ Exchange current density of methanol ...........................................Am ${ }^{-2}$

$I_{o, r e f}^{O_{2}} \quad$ Exchange current density of oxygen

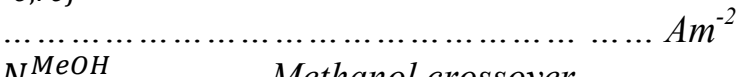
$N_{\text {Cross Over }}^{\mathrm{MeOH}}$ Methanol crossover

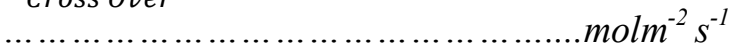

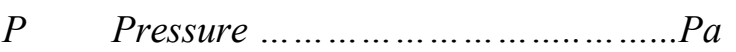

$T \quad$ Temperature............................ K

$\mathrm{UMeOH}_{\mathrm{MeH}} \quad$ Thermodynamic equilibrium potential of methanol oxidation............. Volt

$\mathrm{UO}_{2} \quad$ Thermodynamic equilibrium potential of oxygen oxidation ................. Volt

$V_{\text {cell }} \quad$ Cell voltage........................ Volt

$\mathrm{U}_{2} \quad$ Thermodynamic equilibrium potential of oxygen oxidation. Volt
M Molecular weight $\mathrm{km} / \mathrm{kg}$

\section{Greek}

$\alpha_{A} \quad$ Anodic transfer coefficient

$\alpha_{C} \quad$ Cathodic transfer coefficient

$\delta_{A C} \quad$ Anode Catalyst layer thickness..........m

$\delta_{A D} \quad$ Anode diffuser layer thickness.........m

$\delta_{M} \quad$ Membrane thickness......................m

$\alpha \quad$ Void fraction

$\mu \quad$ Dynamic viscosity ................... $\mathrm{kgm}^{-1} \mathrm{~s}^{-1}$

$\rho \quad$ Density................................ $\mathrm{kgm}^{-3}$

$\eta_{A} \quad$ Anode over potential.................. Volt

$\eta_{C} \quad$ Cathode over potential................ Volt

$\xi^{\mathrm{MeOH}} \quad$ Electro-osmotic drag coefficient of methanol

$\kappa \quad$ Ionic conductivity of the membrane

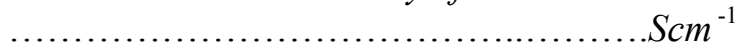
x' Quality

\section{Subscripts}

$A D L$

$A C L$

$M$

\section{Superscripts}

$\mathrm{MeOH}$

$\mathrm{O} 2$

$\mathrm{CO} 2$

K

\section{Anode Diffuser Layer Anode Catalyst Layer} Memberrane

Methanol
Oxygen
Carbon dioxide
Species




\section{Introduction}

Direct methanol fuel cells (DMFCs) are currently being investigated as an alternative power source to batteries for portable applications such as cell phones, laptop computers and video recorders. DMFCs with advantages of high energy density, rapid startup and response, low operation temperature, zero emission and refueling instantly, stand out as a most promising candidate to the applications of present and next generation of portable electronic devices $[1,2]$.Regarding the DMFCs studies have been focused on two categories, materials of the cell and the anode electrochemical reaction. Water, methanol and gas management are the three main issues that some attempts have been investigated to optimize these effects on the cell performance. A good understanding of this complex, interacting phenomena to optimum the design parameters of system leads to numerous experimental and comprehensive mathematical modeling of cells.

Kulikovsky et al. [3] developed a vapor-feed two-dimensional DMFC model. Their model based on the mass conservation equations for concentrations of species and conservation equations of proton and electron currents, which govern the distributions of electrical potentials of the membrane and carbon phases. In his study, he neglected the methanol cross over the membrane.

Wang and Wang [4] presented a 2-D, two-phase model of liquid - feed DMFC. They extended their previous two-phase PEMFC model [5] to include two phase flow and transport phenomena in a liquid feed DMFC.1- D drift flow model was used to describe the methanol flow in the anode channel.

Here a comprehensive 3-D, homogenous two phase model for the anode channel and 1D two phase mathematical modeling for the porous region were considered. This combination model results in the easily managing and optimizing of effective parameters on DMFC.

A typical DMFC consists essentially of a membrane-electrode assembly (MEA) sandwiched between two bipolar plates which have a channel for distribution the fuel, an aqueous methanol solution in the anode and oxygen from air in the cathode, Figure (1).In an operation DMFC, methanol solution diffuses through one of the porous diffusion layer and is oxidize at the anode to produce carbon dioxide, protons and electrons. At the cathode, Oxygen diffuses through another porous diffusion layer and is reduced with the proton passing through the proton exchange membrane as well as electrons flowing through load from the anode to produce water, equations (1), (2) .

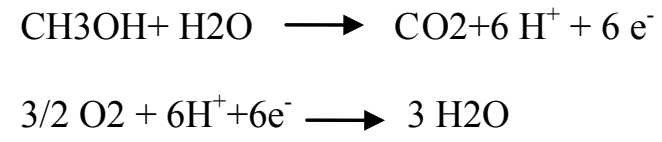

Fig. 1

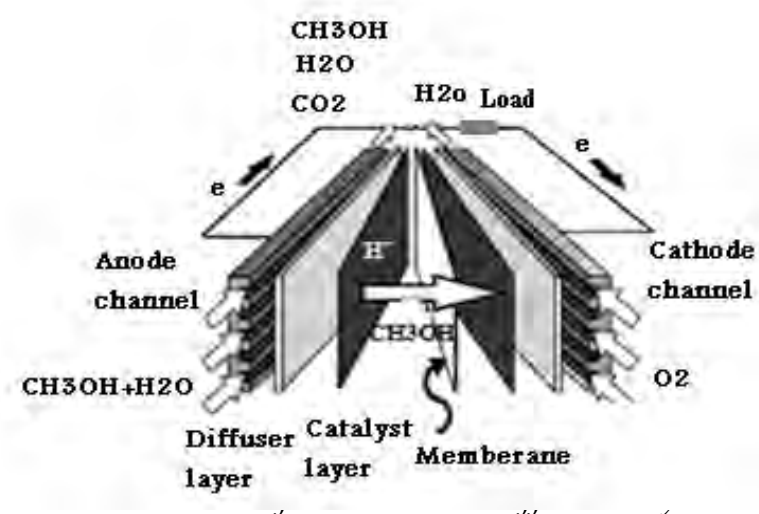

\section{Model description}

Here 3-D homogenous, two phases, multi component flow for the anode channel and 1D two phase mathematical modeling for the porous regions were considered. For the anode channel 
three type of flow patterns, parallel flow field (PFF), single-serpentine flow field (SSFF) and multiple serpentine flow field (MSFF) were considered, fig2.
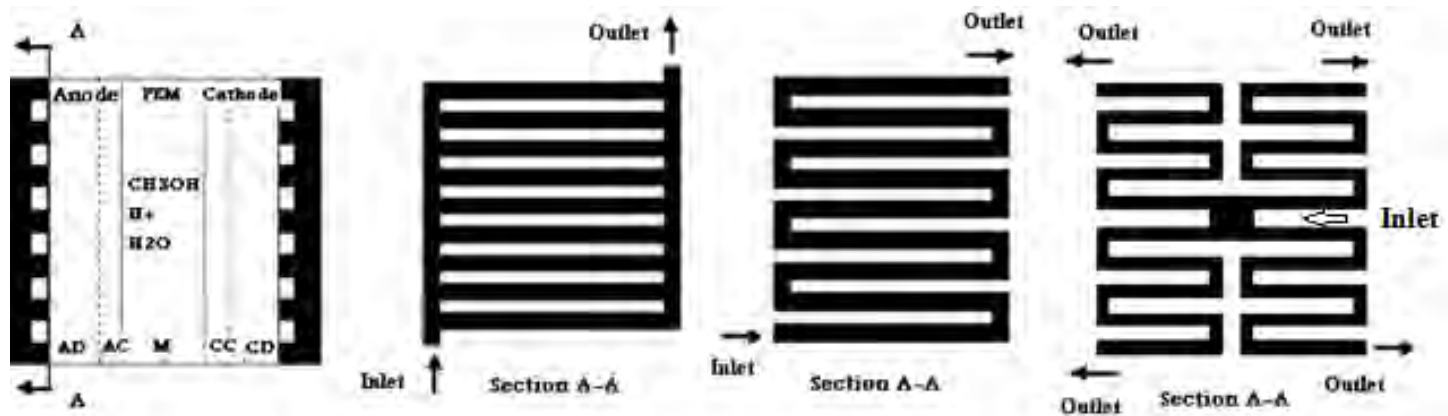

Fig. 2. Schematic view of DMFC with different anode configurations

The combination of CFD modeling and mathematical modeling has been shown in fig3.

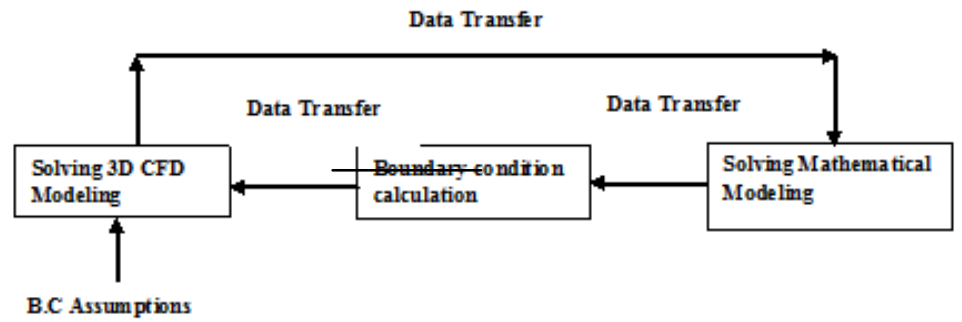

Fig. 3. Coupling CFD modeling and mathematical modeling

\subsection{CFD modeling}

In this study, two phase homogenous model have been used to describe the fluid flow in the anode channel. The study of Triplett [6], Fukano and Kariyasaki [7], showed that the homogeneous model is valid for two-phase bubbly flow because the tube diameter is smaller than $5.6 \mathrm{~mm}$. In this model it is assumed that the thermodynamics equilibrium are available between the phases and two phases are well mixed and therefore travel with the same velocities so the mixture is treated as a pseudo-fluid that obeys the usual equations of singlephase flow.

$\nabla \cdot\left(\rho^{\operatorname{mix}} \vec{U}\right)=0$

$\nabla \cdot\left(\rho^{m i x} \vec{U} \vec{U}\right)=-\nabla P+\nabla \cdot \overleftrightarrow{T}+\rho^{m i x} g$

$T_{i, j}=\mu^{m i x}\left(\frac{\partial u_{i}}{\partial x_{j}}+\frac{\partial u_{j}}{\partial x_{i}}-\frac{2}{3} \delta_{i, j} \frac{\partial u_{n}}{\partial x_{n}}\right)$

$\nabla \cdot\left(\rho^{\text {mix }} \vec{U} C^{k}\right)=\nabla \cdot\left(\rho^{\text {mix }} D^{k} \nabla C^{\mathrm{k}}\right)$

$\rho^{m i x}=\alpha \rho_{l}+(1-\alpha) \rho_{g}$

$\alpha$ is void fraction and related to quality $x$, by,

$\alpha=\frac{1}{1+\left(\frac{1-x}{x}, \frac{\rho_{g}}{\rho_{l}}\right)}$

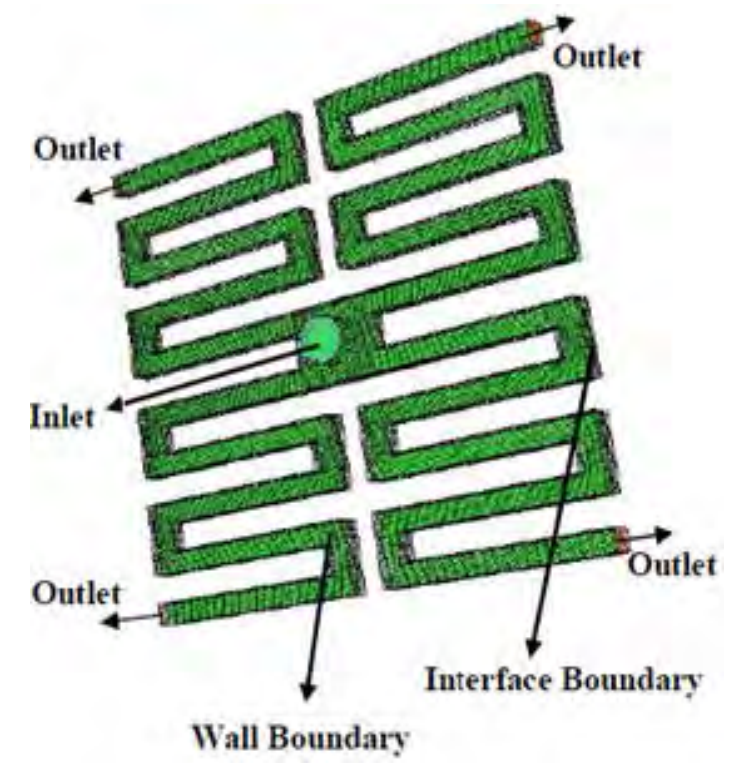


Fig. 4. MSFF configuration, boundary conditions and Meshing Scheme

$x^{\prime}=\frac{\rho_{g}\left(X_{g}^{\mathrm{CO} 2}+X_{g}^{\mathrm{H} 2 \mathrm{O}}+X_{g}^{\mathrm{MeOH}}\right)}{\rho_{l}\left(X_{l}^{\mathrm{H} 2 \mathrm{O}}+X_{l}^{\mathrm{MeOH}}+X_{l}^{\mathrm{CO} 2}\right)}$

The Isbin equations have been used to calculate the mixture viscosity [8].

$\frac{1}{\mu^{m i x}}=x^{\prime} \frac{1}{\mu_{l}}+\left(1-x^{\prime}\right) \frac{1}{\mu_{g}}$

\subsection{Boundary Conditions}

Fig 4 shows the view of MSFF with the different boundary conditions. In the inlet, mass flow rate of dilute methanol is defined. In the outlet, fully developed condition for the SSFF, MSFF and pressure outlet for the PFF is applied. In the boundary between the anode channel and diffuser layer the mass fraction of $\mathrm{MeOH}$ and $\mathrm{CO} 2$ are defined.

\subsubsection{Channel/ Anode diffuser layer interface boundary conditions}

Consumed methanol in the anode catalyst layer and methanol cross over the membrane are equal to methanol transfer due to convection and diffusion in Channel/ Anode diffuser layer,

$\rho^{\text {mix }} \vec{U} \cdot \vec{n} X^{M e O H}+\rho^{\text {mix }} D^{M e O H} \frac{\partial X^{M e O H}}{\partial X}=M^{M e O H} \frac{I_{\text {cell }}}{6 F}+M^{M e O H} N_{\text {Cross Over }}^{M e O H}$

The consumptions of the methanol, water and methanol crossover are equal to the total mass flow rate that goes out of the interface, so

$\rho^{\text {mix }} \vec{U} \cdot \vec{n}=M^{M e O H} \frac{I_{\text {cell }}}{6 F}+M^{M e O H} N_{\text {Cross Over }}^{\mathrm{MeOH}}+M^{H 2 O} \frac{I_{\text {cell }}}{2 F}$

If we replace the $\rho^{\text {mix }} \vec{U} \cdot \vec{n}$ from equation (16) into the equation (15) it gives the diffusion flux from the channel into the diffuser layer.

$\rho^{\text {mix }} D^{\mathrm{MeOH}} \frac{\partial X^{\mathrm{MeOH}}}{\partial x}=M^{\mathrm{MeOH}} \frac{I_{c e l l}}{6 \mathrm{~F}}\left(1-X^{\mathrm{MeOH}}\right)+M^{\mathrm{MeOH}} N_{\text {Cross Over }}^{\mathrm{MeOH}}\left(1-X^{\mathrm{MeOH}}\right)+$ $M^{H 2 O} \frac{I_{c e l l}}{2 F} X^{M e O H}$

For the carbon dioxide the diffusion flux, which comes into the channel via the diffuser layer is equal to the $\mathrm{CO} 2$ production in anode catalyst layer ,diffusion via convection neglected, so,

$\rho^{m i x} D^{c o 2} \frac{\partial X^{c o 2}}{\partial x}=M^{c o 2} \frac{I_{c e l l}}{6 F}$

\subsection{Mathematical modeling}

The porous media regions are divided to the diffuser, catalyst and membrane layer, Fig4. Mathematical modeling has been studied in the detail by Brenda[9]. Here only the results have been shown,

$$
\mathrm{C}_{\mathrm{AC}}^{\mathrm{MeOH}}=\frac{\mathrm{I}_{\mathrm{Cell}}}{12 \mathrm{~F} \delta_{\mathrm{AC}} \mathrm{D}_{\mathrm{AC}}^{\mathrm{MeOH}}} \mathrm{X}^{2}+\mathrm{C}_{1} \mathrm{X}+\mathrm{C}_{2}
$$

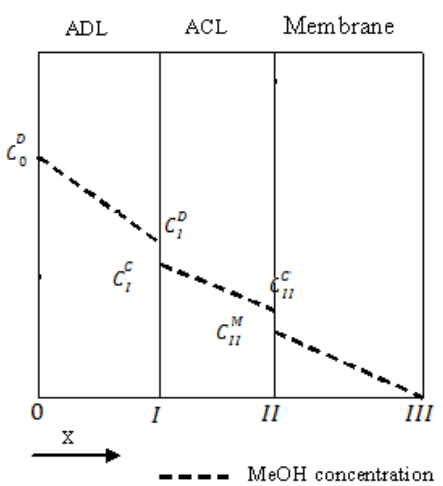




$$
\begin{aligned}
\mathrm{C}_{1} & =\frac{\mathrm{C}_{\mathrm{II}}^{\mathrm{C}}-\mathrm{C}_{\mathrm{I}}^{\mathrm{C}}}{\delta_{\mathrm{AC}}}-\frac{\mathrm{I}_{\mathrm{Cell}}\left(2 \delta_{\mathrm{AD}}+\delta_{\mathrm{AC}}\right)}{12 \mathrm{~F} \delta_{\mathrm{AC}} \mathrm{D}_{\mathrm{AC}}^{\mathrm{MeOH}}} \\
\mathrm{C}_{2} & =\mathrm{C}_{\mathrm{I}}^{\mathrm{C}}-\frac{\left(\mathrm{C}_{\mathrm{II}}^{\mathrm{C}}-\mathrm{C}_{\mathrm{I}}^{\mathrm{C}}\right) \delta_{\mathrm{AD}}}{\delta_{\mathrm{AC}}}+\frac{\mathrm{I}_{\mathrm{cell}} \delta_{\mathrm{AD}}\left(\delta_{\mathrm{AD}}+\delta_{\mathrm{AC}}\right)}{12 \mathrm{~F} \delta_{\mathrm{AC}} \mathrm{D}_{\mathrm{AC}}^{\mathrm{MeOH}}} \\
\mathrm{C}_{\mathrm{I}}^{\mathrm{C}}= & \frac{\delta_{\mathrm{AC}} \mathrm{D}_{\mathrm{M}}^{\mathrm{MeOH}} \mathrm{K}_{\mathrm{II}}\left(\mathrm{D}_{\mathrm{AD}}^{\mathrm{MeOH}} \mathrm{C}_{0}^{\mathrm{D}}-\frac{\mathrm{I}_{\mathrm{cell}} \delta_{\mathrm{AD}}}{12 \mathrm{~F}}\right)+\delta_{\mathrm{M}} \mathrm{D}_{\mathrm{AC}}^{\mathrm{MeOH}}\left(\mathrm{D}_{\mathrm{AD}}^{\mathrm{MeOH}} \mathrm{C}_{0}^{\mathrm{D}}-\left(1+6 \xi_{\mathrm{MeOH}}\right) \frac{\mathrm{I}_{\text {cell }} \delta_{\mathrm{AD}}}{6 \mathrm{~F}}\right)}{\mathrm{D}_{\mathrm{AD}}^{\mathrm{MeOH}} \mathrm{K}_{\mathrm{I}}\left(\delta_{\mathrm{AC}} \mathrm{D}_{\mathrm{M}}^{\mathrm{MeOH}} \mathrm{K}_{\mathrm{II}}+\delta_{\mathrm{M}} \mathrm{D}_{\mathrm{ACL}}^{\mathrm{MeOH}}\right)+\delta_{\mathrm{AD}} \mathrm{D}_{\mathrm{AC}}^{\mathrm{MeOH}} \mathrm{D}_{\mathrm{M}}^{\mathrm{MeOH}} \mathrm{K}_{\mathrm{II}}} \\
C_{I I}^{C} & \\
= & \frac{\delta_{\mathrm{M}}\left(\mathrm{D}_{\mathrm{AC}}^{\mathrm{MeOH}} \mathrm{D}_{\mathrm{AD}}^{\mathrm{MeOH}} \mathrm{C}_{0}^{\mathrm{D}}-\delta_{\mathrm{AC}} \mathrm{D}_{\mathrm{AD}}^{\mathrm{MeOH}} \mathrm{K}_{\mathrm{I}}\left(1+12 \xi_{\mathrm{MeOH}}\right) \frac{\mathrm{I}_{\mathrm{Cell}}}{12 \mathrm{~F}}-\delta_{\mathrm{AD}} \mathrm{D}_{\mathrm{AC}}^{\mathrm{MeOH}}\left(1+6 \xi_{\mathrm{MeOH}}\right) \frac{\mathrm{I}_{\mathrm{cell}}}{6 \mathrm{~F}}\right)}{\mathrm{D}_{\mathrm{AD}}^{\mathrm{MeOH}} \mathrm{K}_{\mathrm{I}}\left(\delta_{\mathrm{AC}} \mathrm{D}_{\mathrm{M}}^{\mathrm{MeOH}} \mathrm{K}_{\mathrm{II}}+\delta_{\mathrm{M}}^{\mathrm{MeOH}}\right)+\delta_{\mathrm{AD}} \mathrm{D}_{\mathrm{AC}}^{\mathrm{MeOH}} \mathrm{D}_{\mathrm{M}}^{\mathrm{MeOH}} \mathrm{K}_{\mathrm{II}}}
\end{aligned}
$$

The operation conditions, geometry and physicochemical properties have been come in table 1 and 2.

Table 1. Operation and Geometry values

\begin{tabular}{lcl}
\hline \multicolumn{1}{c}{ Parameters } & Symbols & Values \\
\hline Operation Temperature & $\mathrm{T}$ & $60^{\circ} \mathrm{c}$ \\
Operation Pressure & $\mathrm{P}$ & $1 \mathrm{At}$ \\
Rib Height & $H$ & $0.001(\mathrm{~m})$ \\
Rib Width & $W$ & $0.0013(\mathrm{~m})$ \\
Diffuser layer thickness & $\delta_{A D}$ & $0.0015(\mathrm{~m})$ \\
Catalyst layer thickness & $\delta_{A C}$ & $0.00023(\mathrm{~m})$ \\
Membrane layer thickness & $\delta_{M}$ & $0.0018(\mathrm{~m})$ \\
\hline
\end{tabular}

Table 2. Physicochemical properties

$$
\text { Parameters }
$$

Binary diffusion coefficient

Binary diffusion coefficient

$\mathrm{MeOH}$ diffusion coefficient,diffuser layer

$\mathrm{MeOH}$ diffusion coefficient,catalyst layer

Methanol diffusion coefficient,memberane

Thermodynamic potential of oxygen (Volt)

Thermodynamic potential of methanol (Volt)

Ref, exchange current density of anode $(\mathrm{A} / \mathrm{m} 2)$

Ref, exchange current density of cathode (A/m2)

Anodic transfer coefficient

Cathodic transfer coefficient

Ionic conductivity of the membrane $(\mathrm{S} / \mathrm{Cm} 2)$

Electro-osmotic drag coefficient

Partition coefficient

Partition coefficient

\begin{tabular}{lc} 
Symbols & Values \\
\hline$D_{\mathrm{MeOH}-W a t e r}$ & $1.74 \times 10^{-6}$ \\
$D_{\mathrm{CO}-\text { Water }}$ & $3.19 \times 10^{-6}$ \\
$D_{A D}^{\mathrm{MeOH}}$ & $8.7 \times 10^{-3}$ \\
$D_{A C}^{\mathrm{MeOH}}$ & $2.8 \times 10^{-9} e^{2436\left(\frac{1}{353}-\frac{1}{T}\right)}$ \\
$D_{M}^{\mathrm{MeOH}}$ & $4.9 \times 10^{-} e^{2436\left(\frac{1}{353}-\frac{1}{T}\right)}$ \\
$U^{\mathrm{O} 2}$ & 1.24 \\
$U^{\mathrm{MeOH}}$ & 0.03 \\
$I_{0, \text { ref }}^{\mathrm{MeOH}}$ & $94.25 e^{\frac{35570}{R}\left(\frac{1}{353}-\frac{1}{T}\right)}$ \\
$I_{0, \text { ref }}^{O 2}$ & $42.22 e^{\frac{73200}{R}\left(\frac{1}{353}-\frac{1}{T}\right)}$ \\
$\alpha_{A}$ & 0.52 \\
$\alpha_{C}$ & 1.55 \\
$\kappa$ & 0.036 \\
$\xi^{\mathrm{MeOH}}$ & $2.5 X^{\mathrm{MeOH}}$ \\
$K_{I}$ & 0.8 \\
$K_{I I}$ & 0.8 \\
\multicolumn{2}{c}{}
\end{tabular}

Ref 


\section{Performance Evaluation}

To obtain the polarization curve the cell voltage of DMFC can be written as,

$V_{\text {cell }}=U^{O 2}-U^{M e O H}-\eta_{A}-\eta_{C}-\frac{\delta_{\mathrm{MEM}} \mathrm{I}_{\text {Cell }}}{\kappa}$

The over potentials term $\eta_{A}$ and $\eta_{C}$ can be determined from the Tafel equations,

$I_{\text {Cell }}=I_{0, \text { ref }}^{\mathrm{MeOH}} \frac{C_{A C}^{\mathrm{MeOH}}}{C_{\mathrm{MeOH}, \mathrm{ref}}} e^{\alpha_{A} \eta_{A} F / R T}=I_{0, \text { ref }}^{O 2} \frac{C_{o 2}}{C_{o 2, \text { ref }}} e^{\alpha_{C} \eta_{C} F / R T}-I_{\text {leak }}$

$I_{\text {leak }}$ is the leakage current density due to the oxidation of the methanol crossover.

$\frac{\mathrm{I}_{\text {leak }}}{6 \mathrm{~F}}=\mathrm{N}_{\text {Crossover }}^{\mathrm{MeOH}}=\left(-D_{M}^{M e O H} \frac{d C_{M}^{M e O H}}{d x}+\xi^{M e O H} \frac{I_{\text {cell }}}{F}\right)$

\section{Results}

\subsection{Effect of mass flow rate and inlet feed concentration on the cell performance}

The model has been validated by comparison of the results from SSFF configuration with its experimental data from Q. Liao and X. Zhu [10]. The cell performance have been calculated for the methanol inlet feed concentration of $\mathrm{M}=1$, temperature of $60^{\circ} \mathrm{c}$ and two different inlet mass flow rate. As it can be seen the model results are in the good agreement with the experimental data. In the right figure the variation of cell voltage with the current density at different inlet feed concentrations have been shown and it is obvious that the cell performance will improve while the inlet feed concentration increase. The performance improvement from $1 \mathrm{M}$ to $2 \mathrm{M}$ is more than from $0.5 \mathrm{M}$ to $1 \mathrm{M}$. This can be attributed to increasing methanol concentration, which satisfies the additional requirement of the electrochemical reaction in the anode due to higher current densities.

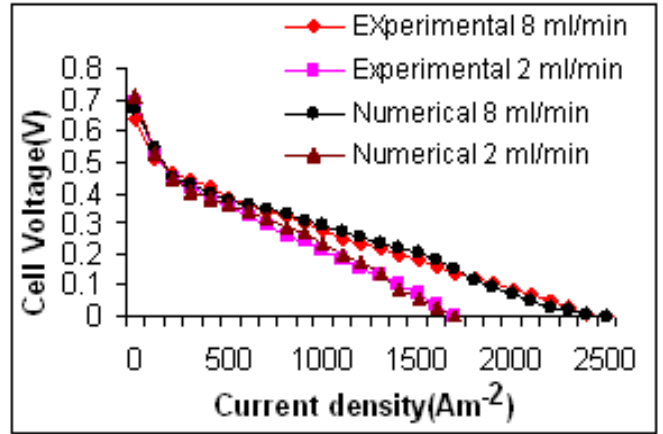

(6.a)

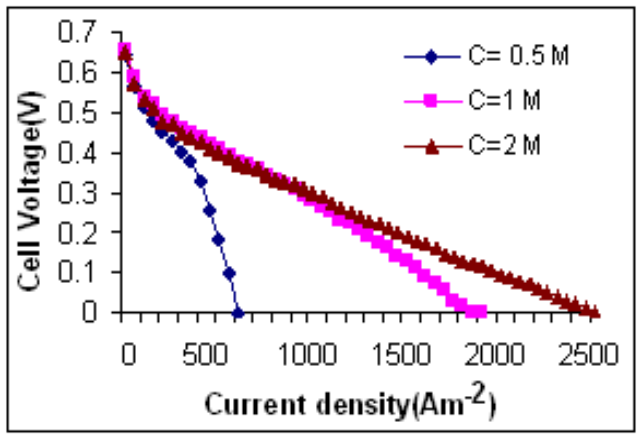

(6.b)

Fig. 6. Numerical and experimental cell data performance for two different inlet mass flow rate (6.a) and Cell performance at different inlet feed concentration (6.b)

\subsection{Effect of flow configuration on $\mathrm{CO} 2$ and methanol concentration}

Distribution of $\mathrm{CO} 2$ molar concentration in the anode channel for different configurations at the inlet feed concentration and current density $2 \mathrm{M}, 1500 \mathrm{~A} / \mathrm{m}^{2}$ respectively, have been shown in fig7.CO2 molar concentration increase incrementally from inlet to outlet and reach the maximum value $0.03,0.025$ and .02 for PFF, SFF and MSFF respectively. Fig8 shows the distribution of methanol molar concentration. Here the methanol concentration decreases incrementally from inlet to outlet and reaches the minimum value of $0.5,0.71$ and 0.81 for $\mathrm{PFF}, \mathrm{SFF}$ and MSFF respectively in the outlet of the channel. The distribution of the $\mathrm{CO} 2$ in 
the MSFF is more smoothly relative to two other cases and the coalescence of gas bubbles in the corner of the ribs are less than other cases.
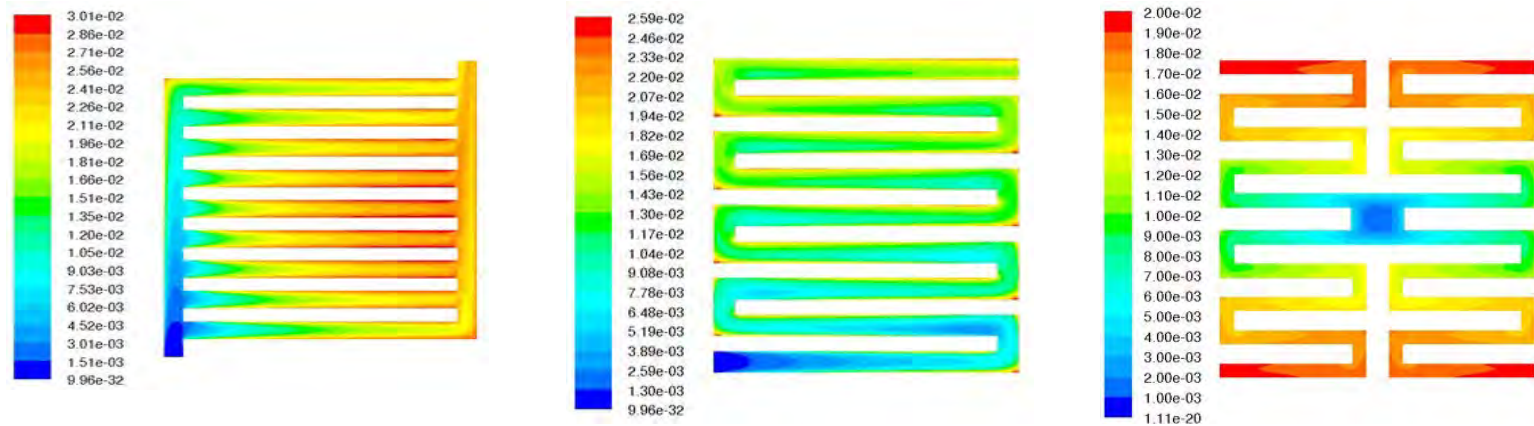

Fig. 7. Distribution of CO2 molar concentration for PFF, SFF and MSFF flow configuration
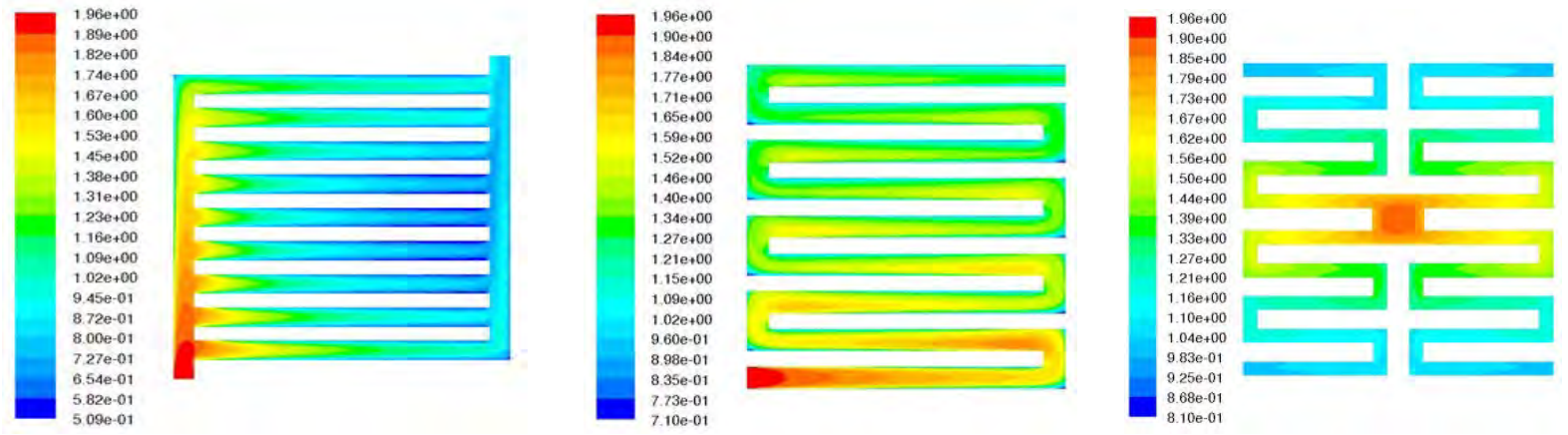

Fig. 8. Distribution of MeOH molar concentration for PFF, SFF and MSFF flow configuration

\subsection{Effect of flow configuration and temperature on the cell performance}

The performance of the cell is depended on the mass fraction of methanol in the catalyst layer that is depended on the average methanol mass fraction in the anode channel. By calculation the cell performance using mentioned combination method, it can be seen that the MSFF configuration has better performance relative two other cases fig9a. In the right picture9.b the effects of temperature on cell performance have been shown. As it can be seen with increasing the temperature the cell performance will increase, especially at high current density.
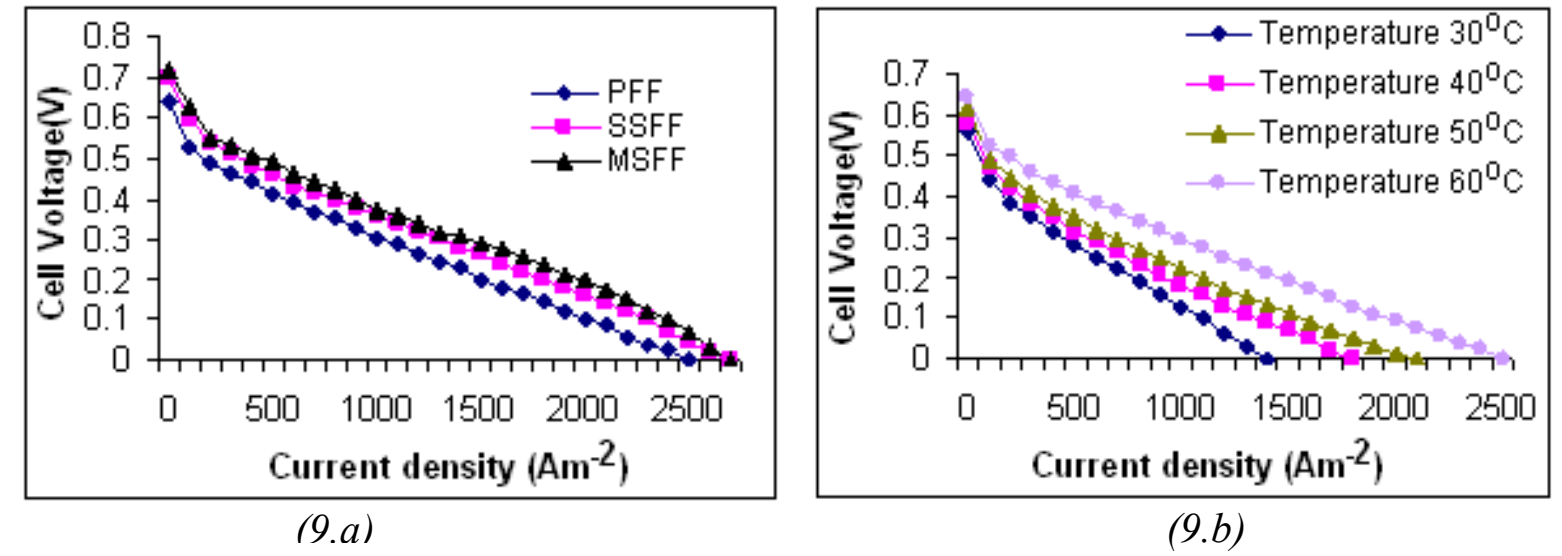

Fig. 9. Comparison of anode configuration on cell voltage (9.a) and effects of temperature on cell performance (9.b) 


\section{Conclusions}

DMFCs have the following advantages; easy fuel delivery and storage, no need for cooling or humidification, simpler system design and may even achieve higher overall energy efficiency than PEMFCs with further developments. This new modeling design is the way to find the exact cell performance with different geometry. From the results, MSFF flow configuration can give a better performance relative to two other cases so this kind of cell geometry can solve the problems regarding lower overall energy efficiency of DMFCs relative to PEMFCs.

\section{References}

[1] C.K. Dyer, Fuel Cells for Portable Applications, J. Power Sources 106 (2002) 31-34.

[2] K. Cowey, K.J. Green, G.O. Mepsted and R. Reeve, Portable and military fuel cells, Curr. Opin. Solid State Mater. Sci. 8 (2004) 367-371.

[3] A. Kulikovsky, J. Divisek and A.A. Kornyshev, Two-dimensional simulation of direct methanol fuel cells, a new type of current collector, J. Electrochem. Soc. 147 (2000) 953.

[4] Z.H. Wang and C.Y. Wang, Mathematical modeling of liquid-feed direct methanol fuel cells, J. Electrochem. Soc. 150 (4) (2003) 508-519.

[5] Z.H. Wang, C.Y. Wang and K.S. Chen, Two-phase flow and transport in the air cathode of proton exchange membrane fuel cells, J. Power Sources 94 (2001) 40-50.

[6] K.A. Triplett, S.M. Ghiaasiaan, S.I. Abdel-Khalik, A. LeMouel and B.N.Mc- Cord, Gasliquid two-phase flow in microchannels, Part II, Int. J. Multiphase Flow 25 (1999) 395.

[7] T. Fukano and A. Kariyasaki, Characteristics of gas-liquid two-phase flow in a capillary tube, Nucl. Engng. Des 141 (1993) 59.

[8] H.S. Isbin, R.H. Moen, R.O. Wickey, D.R. Mosher and H.C. Larson, Two-phase Steam Water Pressure Drops, Nuclear Science and Engineering, Conference, Chicago,1958

[9] G.L Brenda , A.S. Vijay, J.W. Weidner and R. E. White, Mathematical Model of a Direct Methanol Fuel Cell Journal of Fuel Cell Science and Technology Nov, 2004, Vol. $1 / \operatorname{Pp} 43-48$

[10]L. Qiang, Z. Xun, Z. Xueyan and D. Yudong, Visualization study on the dynamics of $\mathrm{CO} 2$ bubbles in anode channels and performance of a DMFC, Journal of Power Sources 171 (2007) 644-651

[11]A. A. Kulikovsky, J. Divisek, and A. A. Kornyshev, Two-Dimensional Simulation of Direct Methanol Fuel Cell A New (Embedded) Type of Current Collector, Journal of the Electrochemical Society, 147 (3) 953-959 (2000)

[12]K. Scott,W. Taama and J. Cruickshank, Performance and Modeling of a Direct Methanol Solid Polymer Electrolyte Fuel Cell, J. Power Sources 65(1-2),1997, pp. 159-171.

[13]S.F. Baxter, V.S. Battaglia and R.E. White, Methanol Fuel Cell Model: Anode, Journal of the Electrochem Society, 1999, 146(2), pp. 437-447.

[14]X. M. Ren, T. E, Springer, T.A. Zawodzinski and S.Gottesfeld, Methanol Transport through Nafion Membranes, J. Electrochem Society, 2000. 147(2), pp. 466-474.

[15]A. Parthasarathy, S. Srinivasan, A.J. Appleby and C. R. Martin,Temperature Dependence of the Electrode Kinetics of Oxygen Reduction at the Platinum/Nafion Interface, a Microelectrode Investigation, J. ElectrochemSociety, 1992, 139(9), pp. 2530-2537. 